\title{
Essays
}

\section{"How did researchers get it so wrong?" The acute problem of plagiarism in Vietnamese social sciences and humanities}

\author{
Quan-Hoang Vuong \\ Thanh Tay University, Yen Nghia, Ha Dong district, Hanoi, Vietnam \\ Université Libre de Bruxelles, 50 Ave. F.D. Roosevelt, Brussels, Belgium; qvuong@ulb.ac.be
}

DOI: 10.20316/ESE.2018.44.18003

\begin{abstract}
This paper presents three cases of research ethics violations in the social sciences and humanities that involved major educational institutions in Vietnam. The violations share two common points: the use of sophistry by the accused perpetrators and their sympathisers, and the relative ease with which they succeeded unpunished. The strategies the violators used to avoid punishment could be summarised as: (i) relying on people not paying enough attention when asked to do something relatively quickly, (ii) asking for the benefit of the doubt, (iii) redefining the meaning of ethics, and (iv) defaming the whistleblowers and showing how fighting ethics violations is too costly, slow and, in the end, worthless. We offer suggestions to improve transparency: investment in translation and education about codes of conduct in Vietnam; investment in research ethics and integrity; the use of open online resources and platforms; and educating Vietnamese researchers about international standards.
\end{abstract}

Keywords: research ethics, plagiarism, social sciences and humanities, Vietnam, transparency

\section{Introduction}

Vietnam is a fast-growing emerging economy in Southeast Asia, with 96 million people and a "golden population structure", in which 69\% are at the working age (15-64 years), ${ }^{1}$ and more than 17.27 million are students in K-12 and colleges or universities. ${ }^{2}$ With a GDP of USD 220 billion in 2017, Vietnam is allocating increasing amounts of funding to sciences from both the government (about $2 \%$ of total state budget, or $0.5 \% \mathrm{GDP})^{3}$ and the public (including private education institutions). Nonetheless, the social sciences and humanities have low productivity. ${ }^{4,5}$ When criticised for low productivity in terms of international publications, Professor Le Huu Nghia from the National Academy of Administration made an implausible counterargument, alluding to the "sensitive" nature of Vietnamese social sciences. ${ }^{6}$ However, what is more serious, is that Vietnamese research activities show a worrying degree of ethics violations. Three prominent casese are summarised below.

\#1: In 2010, a well-known (male) professor of economics, Tran Ngoc Tho, at the University of Economics Ho Chi Minh City was found to have completely plagiarised the book International Financial Management written by Jeff Madura. ${ }^{7}$ The Vietnamese book had been used for 7 years without any detection of the plagiarism. The scandal itself started with a prior scandal. Another (female) professor, Phan Thi Cuc, Dean of Banking Finance at the Industrial University of Ho Chi Minh City had plagiarised the plagiarised book of Professor Tho. When this was detected, Professor Tho's criticised Professor Cuc harshly. Professor Cuc was subsequently admitted to hospital. ${ }^{8}$

\#2: In 2015, Dr Dao Duc Doan, Dean of Political Theorising and Citizen Education at Hanoi Pedagogical University, served as a jury member of a doctoral candidate, Bui Thi Thanh Huyen. A few months later, a Masters student, Tran Van Hai, also a teacher from Can Tho University, who was supervised by Dr Doan, submitted his final thesis. Hai plagiarised almost all of Huyen's doctoral dissertation. The mentor, Dr Doan, tried to put the blame on his student, saying that he had put too much trust in his supervisee. When the case was examined by the University, all the people involved were found guilty. ${ }^{9}$

\#3: In February 2018, in a report sent to the State Council of Professor Title of Vietnam, a high-ranking official of Vietnam's Ministry of Education was accused of selfplagiarism and fabricated citation in his two publications in the journal Asian Social Science. The author of the report requested the Council to consider removing the formal Professor Title from this official. ${ }^{10}$ The accused party chose to remain silent: a member of the State Council defended the official claiming that an author can re-use his work, and that there is no such concept as self plagiarism in the Vietnamese language. ${ }^{11}$

As the list of research ethics violations in Vietnamese social sciences and humanities grows, ${ }^{12,13,14,15}$ we have to ask: "How did researchers get it so wrong?" In the next sections we offer some explanations.

\section{Minimising the damage}

A violator can always establish a strategy to minimise his or her loss if the ethical violation is detected and, in many cases, the violator can slip through any existing punishment mechanism. We will show you how.

\section{a) Time will sort out all problems if people do not pay attention to them.}

Cuc and her collaborators at the Industrial University 
in the plagiarism case were disciplined by the Ministry of Education and Training, with the punishment being a rebuke. ${ }^{16}$ What is a rebuke? Basically, nothing. All the plagiarists got away with the serious violation of ethics they had committed. Two years later, in 2012, a reader of this news reported that after the punishment the plagiarising book was reprinted again and again as the required textbook for students at the Industrial University.

\section{b) "Give us the benefit of the doubt, please!"}

In this strategy, the violators emphasise their good sides and ask the public to be lenient; essentially, the violators ask to be given the benefit of the doubt. For this strategy to work, the following sophistry can be useful: (1) Yes, he/she is a violator. But he/she is a good person and this is his/her first (detected) violation. (2) Given our benevolent attitude and intention to serve society and the public, violations of ethics can be justifiable (The end justifies the means). (3) You (the public) might be a violator someday, and will need the benefit of the doubt, so please give it to us and be lenient. (4) Even though research ethics were violated, we already "observed" the best possible and attained the highest ethics, by all means. Ethical violation should be regarded as an unimportant shortcoming.

This strategy is likely to be efficiently aided by the collective power of academic networks, the focus on social harmony and "saving face" (体面 or thể diện). ${ }^{17}$

Case \#1, The public and the education system accepted that Tho's plagiarism could be ignored, and the public (including thousands of his former and current students) tried to give him the benefit of the doubt. The Confucian system states that face-saving is one of the most important values. So, if a student says that his professor is a plagiarist, the student tends to lose face first. Here, there are some crucial differences between the concept of "face" in Western and Eastern cultures. In the West, if a person commits a wrongdoing, that person alone loses face. In the East, a person's reputation is linked to their community, ${ }^{18}$ so if an individual in the East loses face, their whole community is affected.

Case \#2, Doan tried to defend himself as follows: (i) the plagiarist (his student) was a trustworthy person, mature, with an excellent learning attitude; (ii) he and his student worked really hard and always strived to follow the schedule and meet deadlines; (iii) his student was an experienced manager in the education management system; (iv) the student had "followed the proper process". All these arguments asserted that the violation of research ethics should be considered unimportant and negligible.

\section{c) Redefining the meaning of ethics.}

In case \#1, Tran Thanh Tuyen - Rector of the University when the plagiarising book was published - tried to support Tho by showing that the highest ethics is the act of serving the public, in this case having a modern textbook for students. He asserted that "patriotic ethics" should supersede research ethics. d) Stop whistleblowers by defaming them and showing the public that fighting ethics violations is too costly, slow and finally worthless.

In case \#1, Tho received no punishment at all and did not even make an apology. His former rector, Tuyen, appeared in the media trying to rebut all the rightful accusations with lengthy, illogical and unethical arguments that nobody really understood. These efforts drew support from thousands of former students in defaming whoever dared to tell the truth.

Case \#2: Doan remains the Dean of the Faculty for a simple reason: "There is no new decision to appoint a new Dean". ${ }^{11}$

Such failure of institutions to deal with staff and students who commit research misconduct is disheartening for honest researchers and deters those who detect violations from acting on their findings.

\section{Discussion}

We have described three cases which show that the culture of social sciences and humanities in Vietnam tolerates violations of research ethics and fails to punish perpetrators. Addressing this will require education and support from researchers in other countries. International guidelines exist that can be translated and disseminated to Vietnamese institutions. The UK, EU, US, Japan, Australia, and China have given official aid to Vietnam over the past decades, and now seek ways to improve the quality of their support. One approach would be to work with leading Vietnamese organisations such as the National Foundation for Science and Technology Development, the institution tasked with building scientific capacity through merit based funding allocation. Funding organisations and research institutions need to validate ethical codes for their staff and students and establish committees of research ethics.

Investments in science need to be matched by increased investment in research ethics and scientific integrity. This is not a private matter: failure to invest in research ethics could exacerbate the problem of misallocation of scarce funding.

Another option is for the Government's science administration agencies to require researchers in public institutions or receiving public funding to abide strictly by all basic rules and regulations on research ethics. Researchers can make use of available online systems for sharing published works, at least for peer assessments, especially if the researchers are from the public institutions and use public funding. The introduction to online communities such as PubPeer or Retraction Watch could be immensely helpful to improve transparency in Vietnam's social sciences and humanities.

Finally, changes must come from the Vietnamese researchers themselves; they should seek to leave their comfort zone and engage more with international scientific dialogues. Clinging on to the misguided excuse that Vietnamese social sciences and humanities are too 'sensitive' for publication in international journals ${ }^{4,8}$ will only hold back the researchers from ever progressing. As long as Vietnamese researchers remain unexposed to international standards, it is hard to imagine a future where plagiarism and sophistry become rarer let alone impossible to consider in Vietnam's social sciences and humanities. 


\section{Funding}

This paper is funded by Vietnam National Foundation for Science and Technology Development (NAFOSTED) under the National Research Grant No. 502.01-2018.19.

\section{References}

1 Vietnam News Agency. Population ageing challenges Vietnam. VietnamPlus: https://en.vietnamplus.vn/population-ageingchallenges-vietnam/119955.vnp (2017, accessed March 08, 2018).

2GSO. Statistical data. General Statistics Office of Vietnam, 2016. https:// www.gso.gov.vn/SLTK/Menu.aspx?rxid=1fcd9551-176f-46c5-b0fb9dcc84666777\&px_db=10.+Gi\%C3\%A1o+d\%E1\%BB\%A5c\&px_ type $=$ PX\&px_language $=$ vi (accessed March 09, 2018).

3 Editorial. Vietnam expects GDP growth rate of 6.4-6.8\% in 2018. Nhan Dan: http://en.nhandan.com.vn/business/item/5324902-vietnamvalues-icao\%E2\%80\%99s-technical-support-to-aviation-industry.html (2017, accessed March 09, 2018).

4 Bich-Ngoc. Why do social science and humanities fall short of international publications? [article in Vietnamese]. VnExpress: https:// vnexpress.net/tin-tuc/khoa-hoc/trong-nuoc/vi-sao-khoa-hoc-xa-hoiva-nhan-van-it-co-cong-bo-quoc-te-3745891.html (2018, accessed July 04, 2018).

5 Nguyen T-H. Social Science \& Humanities research: reasons behind difficulty in international publications [article in Vietnamese]. Tia Sang: http://tiasang.com.vn/-quan-ly-khoa-hoc/Nghien-cuuKHXHNV-Nguyen-nhan-kho-cong-bo-quoc-te-10034 (2016, accessed July 04, 2018).

6 Thanh-Nhan. International publications: Don't worry about sensitive issues [article in Vietnamese]. VietnamNet: http://vietnamnet.vn/ vn/giao-duc/khoa-hoc/cong-bo-quoc-te-dung-lo-de-tai-nhaycam-370596.html (2017, accessed July 04, 2018).

7 Editorial. Tragedy of the professor accused of plagiarizing others' book [article in Vietnamese]. Đất Việt: http://baodatviet.vn/giao-duc/ bi-kich-giao-su-tien-si-bi-to-luoc-sach-cua-nguoi-la-2284252/ (2018, accessed July 5 2018).

8 Le DT. Intellectual corruption and the collapse of teachers' integrity [article in Vietnamese]. Sức Khỏe \& Đời Sống: http://suckhoedoisong. vn/tham-nhung-tri-tue-va-su-do-vo-nhan-cach-nguoi-thay-n4253. html (2010, accessed March 09, 2018).

9 Editorial. Hanoi Pedagogical University: Many staff disciplined for 'plagiarism' [article in Vietnamese]. Lao Động: https://laodong.vn/ ban-doc/truong-dh-su-pham-ha-noi-nhieu-can-bo-bi-ky-luat-vi-vudao-luan-van-681595.bld (2017, accessed March 09, 2018).

10 BBC-Vietnamese. About the accusation of Minister Nha's plagiarism [article in Vietnamese]. BBC Vietnamese: https://www.bbc.com/ vietnamese/vietnam-43193993 (2018, accessed March 09, 2018).

11 BBC-Vietnamese. What does 'self-plagiarism' really mean? [article in Vietnamese]. BBC Vietnamese: https://www.bbc.com/vietnamese/ media-43281095 (2018, accessed March 09, 2018).

12 Thuy-Ngan. We must be tough on plagiarism [article in Vietnamese]. Thanh Niên: https://thanhnien.vn/giao-duc/phai-manh-tay-voi-daovan-487093.html (2012, accessed July 04, 2018).
13 Nguyen H. Thinking about 'plagiarism' from a book [article in Vietnamese]. Nhân Dân: http://www.nhandan.com.vn/ chinhtri/binh-luan-phe-phan/item/20503902-t\%E1\%BB\%ABm\%E1\%BB\%99t-cu\%E1\%BB\%91n-s\%C3\%A1ch,-ngh\%C4\%A9v\%E1\%BB\%81-hi\%E1\%BB\%87n-t\%C6\%B0\%E1\%BB\%A3ng\%C4\%91\%E1\%BA\%A1o-v\%C4\%83n.html (2013, accessed July 04, 2018).

14 Ngan-Anh. The verdict on the accusation of plagiarism of Vice Rector of Hanoi University of Science and Technology [article in Vietnamese]. VietnamNet: http://vietnamnet.vn/vn/giao-duc/ketluan-don-to-cao-hieu-pho-dh-bach-khoa-ha-noi-223547.html (2015, accessed July 04, 2018).

$15 \mathrm{BH}$ Admitting to plagiarism, dean of the department of law withdrew from the list of associate professor nominees [article in Vietnamese]. Lao Động: https://laodong.vn/giao-duc/thua-nhan-dao-van-truongkhoa-luat-xin-rut-khoi-danh-sach-pho-giao-su-593808.ldo (2018, accessed July 04, 2018).

16 Quoc-Dung. Four lecturers of Industrial University of Ho Chi Minh City disciplined for "plagiarizing book" [article in Vietnamese]. An Ninh Thủ Đô: http://anninhthudo.vn/phap-luat/ky-luat-4-giang-viendai-hoc-cong-nghiep-tphcm-vi-dao-sach/372133.antd (2010, accessed March 09, 2018).

17 Bond MH. The Oxford Handbook of Chinese Psychology. Oxford Library of Psychology, 2010.

18 Ho MT, La VP, et al. 'Cultural Additivity' and how the values and norms of Confucianism, Buddhism, and Taoism co-exist, interact, and influence Vietnamese society: A Bayesian analysis of long-standing folktales, using R and Stan. Working Papers CEB N ${ }^{\circ} 18-015$, Université Libre de Bruxelles, March 2018.

\section{A date for your diary}

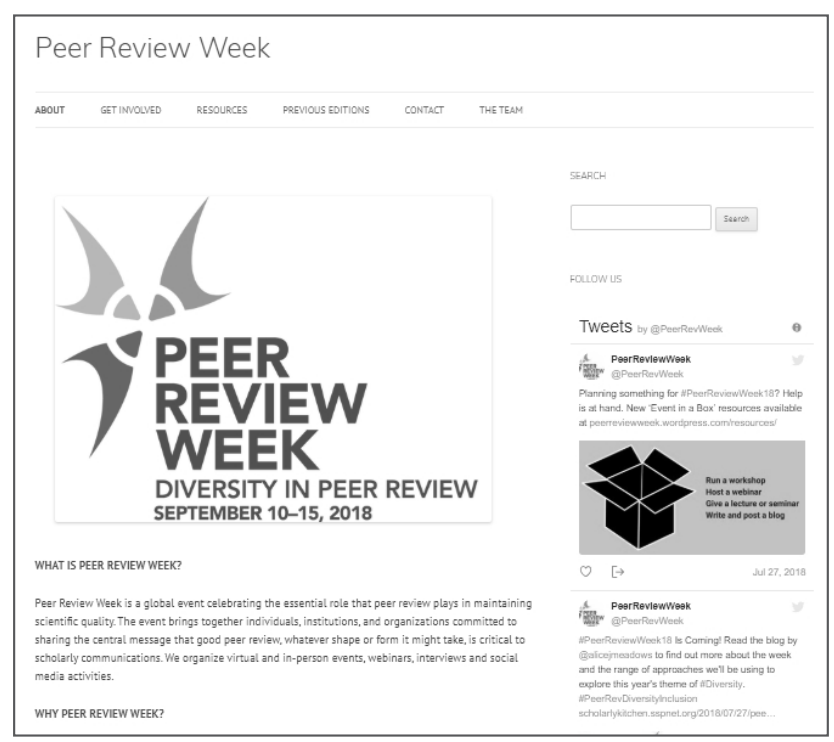

https://peerreviewweek.wordpress.com/ 